\title{
Uji Kandungan Fenolik Total dan Pengaruhnya terhadap Aktivitas Antioksidan dari Berbagai Bentuk Sediaan Sarang Semut (Myrmecodia pendens)
}

Crescentiana Emy Dhurhania*, Agil Novianto

Program Studi D3 Farmasi, Sekolah Tinggi Ilmu Kesehatan Nasional, Surakarta

*Corresponding author: dhurhania@stikesnas.ac.id

\begin{abstract}
Background: Phenolic compounds are the largest group of compounds that act as natural antioxidants in plants. One plant that has high potential as a natural antioxidant is Myrmecodia pendens, which is related to its potential as a source of phenolic compounds. Objective: This study aimed to test the total phenolic content of various dosage form of Myrmecodia pendens and its effect on antioxidant activity. Methods: The qualitative test results showed that in the steeping, stew, and extract of Myrmecodia pendens positively contained phenolic compounds, including flavonoids, tannins and polyphenols. The total phenolic content test was carried out by the Folin-Ciocalteu method using UV-Vis spectrophotometry at $760.5 \mathrm{~nm}$, with results in brew, stew, and extract 3.64; 3.37; $2.74 \mathrm{~g} G A E / 100 \mathrm{~g}$ dry ingredients respectively. The antioxidant activity test was carried out with reduction capacity of cerium by UV-Vis spectrophotometry at $317.5 \mathrm{~nm}$. Results: All preparations, namely brew, stew, and extract, have very strong antioxidant activity with $E C_{50} 6.78 ; 2.45 ; 4.00 \mu \mathrm{g} / \mathrm{mL}$, respectively, while $E C_{50}$ vitamin $C 4.17 \mu \mathrm{g} / \mathrm{mL}$ as comparison. Conclusion: Thus, to get the highest phenolic content with very strong antioxidant activity, dry powder of Myrmecodia pendens should be consumed in the form of brew.
\end{abstract}

Keywords: total phenolic, antioxidant, Myrmecodia pendens preparation

\begin{abstract}
Abstrak
Pendahuluan: Senyawa fenolik merupakan kelompok senyawa terbesar yang berperan sebagai antioksidan alami pada tumbuhan. Salah satu tumbuhan yang berpotensi tinggi sebagai antioksidan alami adalah sarang semut (Myrmecodia pendens). Hal tersebut terkait dengan potensinya sebagai sumber senyawa fenolik. Tujuan: Penelitian ini bertujuan untuk melakukan uji terhadap kandungan fenolik total dari berbagai bentuk sediaan sarang semut dan pengaruhnya terhadap aktivitas antioksidan. Metode: Hasil uji kualitatif menunjukkan bahwa dalam sediaan seduhan, rebusan, dan ekstrak sarang semut positif mengandung senyawa fenolik, antara lain: flavonoid, tanin dan polifenol. Uji kandungan fenolik total dilakukan dengan metode Folin-Ciocalteu secara spektrofotometri UV-Vis pada 760,5 nm, dengan hasil pada seduhan, rebusan, dan ekstrak berturut-turut 3,64; 3,37; 2,74 g GAE/100 g bahan kering. Uji aktivitas antioksidan dilakukan dengan parameter kapasitas reduksi serium secara spektrofotometri UV-Vis pada $317,5 \mathrm{~nm}$. Hasil: Seluruh sediaan sarang semut, yaitu seduhan, rebusan, dan ekstrak memiliki aktivitas antioksidan yang sangat kuat dengan $\mathrm{EC}_{50}$ secara berturut-turut 6,78; 2,45; 4,00 $\mu \mathrm{g} / \mathrm{mL}$, dengan $\mathrm{EC}_{50}$ pembanding vitamin C 4,1685 $\mu \mathrm{g} / \mathrm{mL}$. Kesimpulan: Dengan demikian untuk mendapatkan kandungan fenolik yang paling tinggi dengan aktivitas antioksidan yang sangat kuat, serbuk kering sarang semut sebaiknya dikonsumsi dalam bentuk seduhan.
\end{abstract}

Kata kunci: fenolik total, antioksidan, sediaan Myrmecodia pendens

\section{PENDAHULUAN}

Senyawa fenolik merupakan kelompok senyawa terbesar yang berperan sebagai antioksidan alami pada tumbuhan. Senyawa fenolik memiliki satu (fenol) atau lebih (polifenol) cincin fenol, yaitu gugus hidroksi yang terikat pada cincin aromatis sehingga mudah teroksidasi dengan menyumbangkan atom hidrogen pada radikal bebas. Kemampuannya membentuk radikal fenoksi yang stabil pada reaksi oksidasi menyebabkan senyawa fenolik sangat potensial sebagai antioksidan. Senyawa fenolik alami umumnya berupa polifenol yang membentuk senyawa eter, ester, atau 
glikosida, antara lain flavonoid, tanin, tokoferol, kumarin, lignin, turunan asam sinamat, dan asam organik polifungsional.

Apabila antioksidan enzimatis sebagai sistem pertahanan tubuh tidak lagi memadai untuk menangkal radikal bebas, maka akan mengakibatkan terjadinya stres oksidatif. Pada kondisi stress oksidatif, kelebihan radikal bebas akan bereaksi dengan lemak, protein, dan asam nukleat seluler sehingga memicu peroksidasi lipid membran sel, kerusakan protein maupun asam nukleat yang dapat mengakibatkan hilangnya fungsi seluler secara total. Oleh karena itu, tubuh memerlukan asupan antioksidan untuk mengatasi stres oksidatif. Salah satu tumbuhan yang berpotensi tinggi sebagai antioksidan alami adalah sarang semut (Myrmecodia pendens).

Sarang semut menarik untuk diteliti karena pengalaman empiris penduduk lokal Papua, daerah asal dari tumbuhan ini, telah membuktikan khasiatnya dalam mengatasi berbagai masalah kesehatan. Beberapa penelitian telah membuktikan bahwa sarang semut ( $M$. pendens) memiliki berbagai efek farmakologis, antara lain antibakteri (Attamimi dkk., 2017; Apriyanti dkk., 2016), penurun kadar glukosa darah (Kurniawati \& Sianturi, 2016; Raya dkk., 2016), efek sitotoksisitas terhadap sel kanker (Suharyanto dkk., 2013; Yessica, 2012; Fatmawati dkk., 2011; Soeksmanto dkk., 2010). Selain itu sarang semut juga telah terbukti mampu meningkatkan respon imunologi (Rosyadi \& Hariono, 2017). Berbagai efek farmakologis yang dihasilkan sarang semut terkait dengan potensinya sebagai sumber senyawa fenolik yang bekerja sebagai antioksidan, dengan menangkal radikal bebas yang semuanya mengarah pada terjadinya kerusakan oksidatif. Hal inilah yang mendasari bahwa radikal bebas memberikan kontribusi pada hampir semua jenis penyakit karena dapat menyebabkan kematian sel dan kerusakan jaringan maupun disfungsi organ.

Hingga saat ini, sarang semut dimanfaatkan dalam berbagai bentuk sediaan, yaitu seduhan, rebusan, dan sediaan ekstrak dalam kapsul. Karena senyawa fenolik adalah sumber senyawa antioksidan utama yang terkandung dalam sarang semut, maka berbagai efek farmakologis sarang semut ditentukan oleh kekuatan aktivitas antioksidan yang tidak lain dipengaruhi oleh kandungan fenolik total dalam sediaan sarang semut yang dikonsumsi.

Uji aktivitas antioksidan sarang semut yang pernah dilakukan adalah uji aktivitas antioksidan terhadap fraksi hasil partisi ekstrak sarang semut (Noya dkk., 2013; Suharyanto dkk., 2013). Pengaruh bentuk sarang semut ( $M$. pendens), potongan dan serbuk, suhu ekstraksi, konsentrasi ekstrak, dan interaksinya terhadap total fenolik dan aktivitas antioksidan telah diteliti oleh Setianingsih (2013). Dewi \& Dominika (2008) telah menguji pengaruh suhu penyeduhan terhadap aktivitas antioksidan ekstrak fenol umbi sarang semut (Hydnophytum sp.).

Cara pemanfaatan sarang semut yang digunakan untuk tujuan pengobatan tidak hanya dalam bentuk ekstraknya saja. Justru cara rebusan dan seduhan dari bahan kering adalah cara yang lebih umum digunakan masyarakat dalam mengkonsumsi sarang semut. Melalui penelitian ini, akan diketahui kandungan fenolik total dan pengaruhnya terhadap aktivitas antioksidan dari berbagai bentuk sediaan sarang semut, yaitu seduhan, rebusan, dan ekstrak. Dengan demikian dapat diketahui cara pemanfaatan sarang semut yang paling tepat untuk mendapatkan aktivitas antioksidan yang paling baik dengan kandungan fenolik total yang paling tinggi.

\section{BAHAN DAN METODE \\ Bahan}

Bahan-bahan penelitian yang digunakan, antara lain: serbuk kering bagian umbi tumbuhan sarang semut (Myrmecodia pendens) yang diperoleh dari Wamena Papua; serium sulfat (pro-analysis, Sigma), asam galat (pro-analysis, Sigma), etanol (pro-analysis, E. Merck), metanol (pro-analysis, E. Merck), Reagen Folin Ciocalteu (pro-analysis, E. Merck), $\mathrm{Na}_{2} \mathrm{CO}_{3}$ (pro-analysis, E. Merck), akua bidestilata (Otsuka), akuades.

\section{Alat}

Alat-alat utama yang digunakan antara lain: seperangkat alat spektrofotometer Uv-Vis W-Mini1240, 220-240 Shimadzu (nomor seri A 10934502629) yang dilengkapi dengan kuvet (Helma); neraca analitik ACIS AD-600 dengan sensitivitas penimbangan $0,01 \mathrm{mg}$; alat rotary evaporator (IKA HV 10).

\section{Metode}

\section{Penyiapan sampel seduhan}

Sebanyak 2 g (setara dengan 1 sendok makan) serbuk bahan kering sarang semut ditimbang seksama, kemudian diseduh dengan $200 \mathrm{~mL}$ (setara dengan 1 gelas) akuades mendidih. Seduhan didiamkan 15 menit dalam kondisi tertutup, kemudian disaring. 


\section{Penyiapan sampel rebusan}

Sebanyak 2 g (setara dengan 1 sendok makan) serbuk bahan kering sarang semut ditimbang, kemudian direbus dengan $400 \mathrm{~mL}$ (setara dengan 2 gelas) akuades hingga tersisa 1 gelas $(200 \mathrm{~mL})$. Diamkan 30 menit dalam kondisi tertutup, kemudian disaring.

\section{Penyiapan sampel ekstrak}

Serbuk kering sarang semut ditimbang sebanyak 250 g kemudian dimaserasi dengan 2,5 L etanol $70 \%$ selama 5 hari, sambil dilakukan pengadukan setiap harinya. Setelah 5 hari maserasi dilakukan penyaringan hingga diperoleh filtrat pertama. Ampas yang didapat dikeringkan dalam oven pada suhu $50^{\circ} \mathrm{C}$ selama 24 jam, kemudian dimaserasi kembali dengan cara yang sama hingga diperoleh filtrat kedua. Filtrat pertama dan kedua kemudian dicampur dan dipekatkan dengan rotary evaporator pada kecepatan putar $125 \mathrm{rpm}$ dan suhu $60^{\circ} \mathrm{C}$ hingga diperoleh ekstrak kental. Ekstrak kental kemudian dikeringkan dalam oven pada suhu $50^{\circ} \mathrm{C}$ hingga diperoleh ekstrak kering.

\section{Uji kandungan flavonoid}

Tiap sampel dilarutkan dengan etanol absolut kemudian dibagi menjadi 2 tabung, tabung 1 sebagai larutan blangko dan tabung 2 sebagai larutan uji. Ditambahkan 2 tetes $\mathrm{HCl}$ pekat ke dalam tabung 2, kemudian dibandingkan dengan larutan blangko. Setelah itu tabung 2 dihangatkan di atas penangas air selama 15 menit. Bila terbentuk warna merah atau violet, menunjukkan adanya senyawa flavonoid.

\section{Uji kandungan tannin dan polifenol}

Tiap sampel dilarutkan dengan akuades panas, lalu diaduk dan didinginkan. Ditambahkan 5 tetes $\mathrm{NaCl}$ $10 \%$ kemudian disaring. Filtrat dibagi menjadi 3 tabung, tabung 1 sebagai larutan blangko, tabung 2 dan 3 sebagai larutan uji. Ke dalam tabung 2 ditambahkan 3 tetes $\mathrm{FeCl}_{3}$ dan ke dalam tabung 3 ditambahkan larutan gelatin. Jika terbentuk warna hijau kehitaman pada tabung 2 menunjukkan adanya tanin terhidrolisis, sedangkan jika terbentuk warna hijau kecoklatan menunjukkan adanya tanin terkondensasi. Namun jika terbentuk warna selain warna-warna tersebut maka menunjukkan adanya senyawa polifenol. Jika terbentuk endapan dalam tabung 3 maka menunjukkan adanya tanin.

\section{Uji kandungan fenolik total}

Uji kandungan fenolik total dilakukan dengan metode Folin-Ciocalteu secara spektrofotometri UVVis mengacu pada Nugroho dkk. (2013), dengan baku pembanding asam galat pada rentang $3-7 \mu \mathrm{g} / \mathrm{mL}$ dalam etanol-akuades. Larutan uji dipersiapkan dari sampel seduhan yang dipipet seksama $0,3 \mathrm{~mL}$ dan sampel rebusan $0,2 \mathrm{~mL}$, kemudian ditambah dengan 15,7 mL akuabidestilata untuk sampel seduhan dan $15,8 \mathrm{~mL}$ akuabides untuk sampel rebusan. Adapun sampel ekstrak kering 25,0 mg yang telah dilarutkan dalam 25,0 $\mathrm{mL}$ metanol, dipipet seksama $0,3 \mathrm{~mL}$ kemudian ditambah dengan $15,7 \mathrm{~mL}$ akua bidestilata.

Masing-masing larutan uji ditambah 1,0 mL reagen Folin-Ciocalteu, kemudian dikocok. Setelah didiamkan selama 8 menit lalu ditambah dengan 3,0 mL larutan $\mathrm{Na}_{2} \mathrm{CO}_{3} 20 \%$ dan kocok homogen. Setelah larutan didiamkan selama 2 jam pada suhu kamar, absorbansi diukur pada panjang gelombang maksimum asam galat yang telah direaksikan dengan reagen Folin-Ciocalteu sesuai prosedur di atas yang dipindai pada rentang panjang gelombang 700 $800 \mathrm{~nm}$. Kadar fenolik total dalam sampel dihitung menggunakan persamaan regresi linier, dan dinyatakan dalam asam galat ekuivalen (GAE) per 100 gram bahan kering.

\section{Pengukuran aktivitas antioksidan}

Uji aktivitas antioksidan dilakukan dengan parameter \% kapasitas reduksi serium. Larutan kontrol dibuat dari $1 \mathrm{~mL}$ larutan serium sulfat $2 \times 10^{-3} \mathrm{M}$ yang diencerkan dengan akuades hingga 10,0 mL. Setelah dihomogenkan, larutan dibiarkan selama 30 menit pada suhu kamar. Absorbansi larutan kontrol diukur pada panjang gelombang maksimum serium sulfat dengan akuades sebagai blangko.

Larutan serium sulfat $2 \times 10^{-3} \mathrm{M}$ sebanyak $1 \mathrm{~mL}$ ditambah dengan 50, 60, 70, 80, $100 \mu \mathrm{L}$ larutan sampel seduhan kemudian diencerkan dengan akuades hingga 10,0 mL untuk memperoleh konsentrasi 5; 6; 7; 8; dan $10 \mathrm{ppm}$. Larutan serium sulfat $2 \times 10^{-3} \mathrm{M}$ sebanyak $1 \mathrm{~mL}$ ditambah dengan 10, 15, 20, 25, $30 \mu \mathrm{L}$ larutan sampel rebusan kemudian diencerkan dengan akuades hingga 10,0 mL untuk memperoleh konsentrasi 1; 1,5; 2; 2,5; dan 3 ppm. Adapun sampel ekstrak kering 25,0 mg yang telah dilarutkan dalam 25,0 mL metanol, dipipet seksama 10, 20, 40, 50, $60 \mu \mathrm{L}$ kemudian ditambah dengan larutan serium sulfat $2 \times 10^{-3} \mathrm{M}$ sebanyak $1 \mathrm{~mL}$ dan diencerkan dengan etanol $70 \%$ hingga 10,0 mL untuk memperoleh konsentrasi 1; 2; 4; 5; dan 6 ppm. Setelah dihomogenkan, larutan dibiarkan selama 30 menit pada suhu kamar.

Dengan cara yang sama dilakukan pada larutan vitamin $\mathrm{C}$ sebagai antioksidan pembanding yaitu dengan cara $1,1 \mathrm{~mL}$ larutan Ce (IV) sulfat $2 \times 10^{-3} \mathrm{M}$ ditambahkan larutan vitamin $\mathrm{C}$ dengan variasi 
pemipetan hingga diperoleh konsentrasi 0,$5 ; 1 ; 2 ; 3$; dan 5 ppm kemudian masing-masing larutan diencerkan dengan akuades hingga volume tepat 10,0 mL. Setelah dihomogenkan, campuran larutan didiamkan selama 30 menit pada suhu kamar. Absorbansi dari masing-masing larutan hasil reaksi diukur pada panjang gelombang maksimum serium sulfat dengan akuades sebagai blangko.

Aktivitas antioksidan dinyatakan dengan \% kapasitas reduksi. Persamaan regresi linier dibuat untuk menyatakan hubungan antara konsentrasi larutan dengan \% kapasitas reduksi. Aktivitas antioksidan dinyatakan dengan nilai $\mathrm{IC}_{50}$. Dengan memasukkan angka 50 sebagai $\mathrm{Y}$ dalam persamaan regresi linier, maka akan diperoleh nilai $\mathrm{X}$ sebagai nilai $\mathrm{IC}_{50}$.

\section{HASIL DAN PEMBAHASAN Uji kualitatif}

Sebelum dilakukan penentuan kandungan fenolik total dan pengukuran aktivitas antioksidan, terlebih dulu dilakukan uji kualitatif terhadap masing-masing sampel, meliputi uji kandungan flavonoid, tanin dan polifenol. Hal ini dilakukan karena flavonoid, tanin dan senyawa polifenol merupakan sumber utama senyawa antioksidan dalam sarang semut. Berdasarkan hasil uji kualitatif diketahui bahwa dalam sediaan seduhan, rebusan, dan ekstrak sarang semut positif mengandung flavonoid, tanin dan polifenol.

\section{Uji kandungan fenolik total}

Uji kandungan fenolik total dilakukan dengan metode Folin-Ciocalteu secara spektrofotometri UvVis pada 760,5 nm. Persamaan regresi linier yang digunakan untuk penentuan kandungan fenolik total yaitu $\mathrm{Y}=0,0894 \mathrm{X}+0,0901$, dengan koefisien korelasi (r) 0,9940, pada rentang $3-7 \mu \mathrm{g} / \mathrm{mL}$. Kurva kalibrasi linier yang diperoleh disajikan pada Gambar 1 .

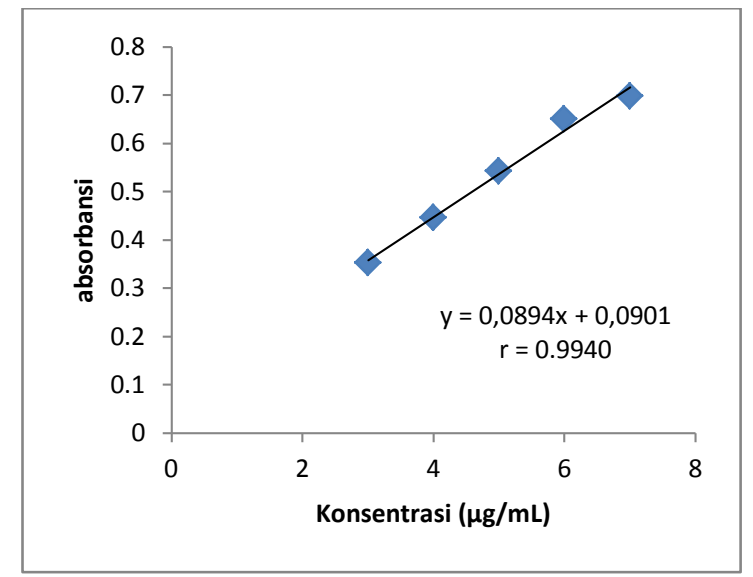

Gambar 1. Kurva kalibrasi linier asam galat
Berdasarkan hasil perhitungan kandungan fenolik total pada berbagai sediaan sarang semut maka urutan sampel yang mampu menghasilkan kandungan fenolik total dari yang paling tinggi, yaitu seduhan 3,64, rebusan 3,37 dan ekstrak 2,74 gram asam galat ekuivalen per 100 gram bahan kering.

\section{Uji aktivitas antioksidan}

Aktivitas antioksidan dinyatakan dengan $\mathrm{EC}_{50}$ (Effectivity Concentration 50), yaitu konsentrasi yang dibutuhkan untuk mereduksi serium sebesar $50 \%$. Aktivitas antioksidan dinyatakan sangat aktif apabila nilai $\mathrm{EC}_{50}$ kurang dari $50 \mu \mathrm{g} / \mathrm{mL}$, aktif apabila memiliki nilai $\mathrm{EC}_{50}$ antara $50-100 \mu \mathrm{g} / \mathrm{mL}$, aktivitas sedang apabila nilai $\mathrm{EC}_{50}$ antara 101 - $250 \mu \mathrm{g} / \mathrm{mL}$, aktivitas lemah apabila nilai $\mathrm{EC}_{50}$ antara $250-500 \mu \mathrm{g} / \mathrm{mL}$, dan dinyatakan tidak aktif apabila memiliki nilai $\mathrm{EC}_{50}$ lebih dari $500 \mu \mathrm{g} / \mathrm{mL}$ (Sabri, 2011).

Pada penelitian ini aktivitas antioksidan diukur dari kapasitas reduksi serium oleh senyawa antioksidan secara spektrofotometri UV-Vis pada $317,5 \mathrm{~nm}$, dengan vitamin $\mathrm{C}$ sebagai pembanding. Berdasarkan penelitian Lung \& Destiani (2017), vitamin C (asam askorbat) merupakan senyawa antioksidan alami yang memiliki aktivitas antioksidan yang sangat tinggi sehingga paling sering digunakan sebagai senyawa pembanding dalam menguji aktivitas antioksidan ekstrak tumbuhan, dibanding senyawa antioksidan alami yang lain yaitu vitamin $\mathrm{A}$ ( $\beta$ karoten) dan vitamin $\mathrm{E}$ ( $\alpha$-tokoferol).

Kapasitas reduksi serium oleh senyawa antioksidan dinyatakan dengan \% kapasitas reduksi, yaitu perbandingan antara jumlah serium yang direduksi oleh senyawa antioksidan terhadap jumlah serium mula-mula. Semakin rendah nilai absorbansi pada hasil pengukuran menunjukkan bahwa $\mathrm{Ce}(\mathrm{IV})$ semakin banyak yang direduksi menjadi Ce(III), sehingga Ce(IV) yang masih tersisa semakin sedikit. Hal tersebut menunjukkan bahwa \% kapasitas reduksi serium oleh senyawa antioksidan semakin meningkat sehingga nilai $\mathrm{EC}_{50}$ semakin kecil dan aktivitas antioksidan semakin meningkat. Kurva hubungan antara konsentrasi dengan \% kapasitas reduksi serium untuk masing-masing sampel dipaparkan pada Gambar $2,3,4$, dan 5 . 


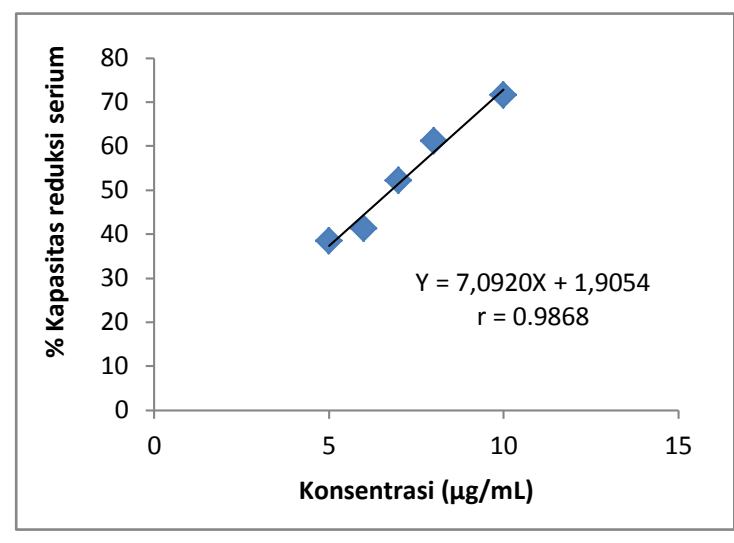

Gambar 2. Kurva hubungan antara konsentrasi sediaan seduhan dengan \% kapasitas reduksi serium

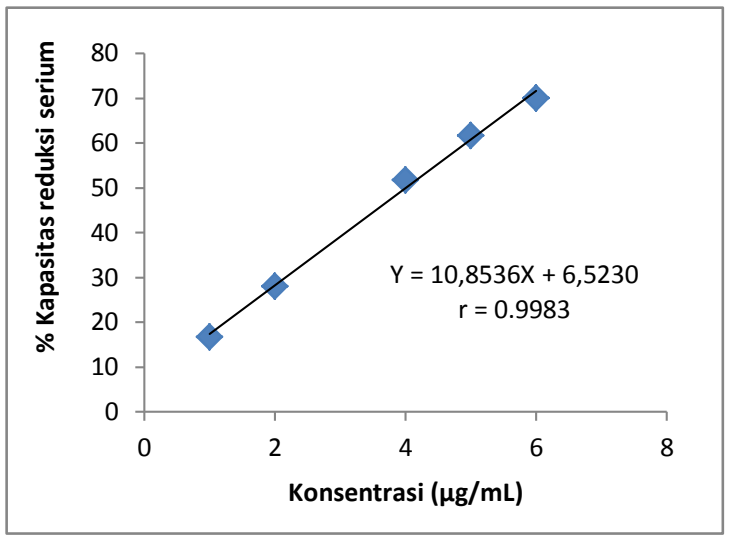

Gambar 4. Kurva hubungan antara konsentrasi sediaan ekstrak dengan \% kapasitas reduksi serium

Kurva pada Gambar 2, 3, 4 dan 5 menunjukkan bahwa semakin tinggi konsentrasi sediaan maka \% kapasitas reduksi serium juga semakin meningkat. Semakin kecil konsentrasi sampel yang dibutuhkan untuk mereduksi serium sebanyak 50\%, maka aktivitas antioksidan dinyatakan semakin kuat. Berdasarkan hasil perhitungan aktivitas antioksidan pada berbagai sediaan sarang semut dan pembanding vitamin $\mathrm{C}$ maka dapat disusun urutan sampel yang mampu memberikan aktivitas antioksidan dari yang paling tinggi, yaitu: sampel rebusan $\mathrm{EC}_{50} 2,45 \mu \mathrm{g} / \mathrm{mL}$, ekstrak $\mathrm{EC}_{50}$ $4,00 \mu \mathrm{g} / \mathrm{mL}$, pembanding vitamin $\mathrm{C} \mathrm{EC}_{50} 4,17 \mu \mathrm{g} / \mathrm{mL}$, dan sampel seduhan $\mathrm{EC}_{50} \quad 6,78 \mu \mathrm{g} / \mathrm{mL}$. Namun demikian, seluruh sediaan sarang semut yang diuji, yaitu seduhan, rebusan, dan ekstrak dapat dinyatakan memiliki aktivitas antioksidan yang sangat kuat atau sangat aktif dengan nilai $\mathrm{EC}_{50}$ kurang dari $50 \mu \mathrm{g} / \mathrm{mL}$.

\section{Analisis hasil}

Berdasarkan kandungan fenolik total yang didapat, maka urutan sediaan sarang semut yang dapat menyajikan kandungan fenolik total dari kadar yang paling tinggi, yaitu seduhan, rebusan, ekstrak. Hal

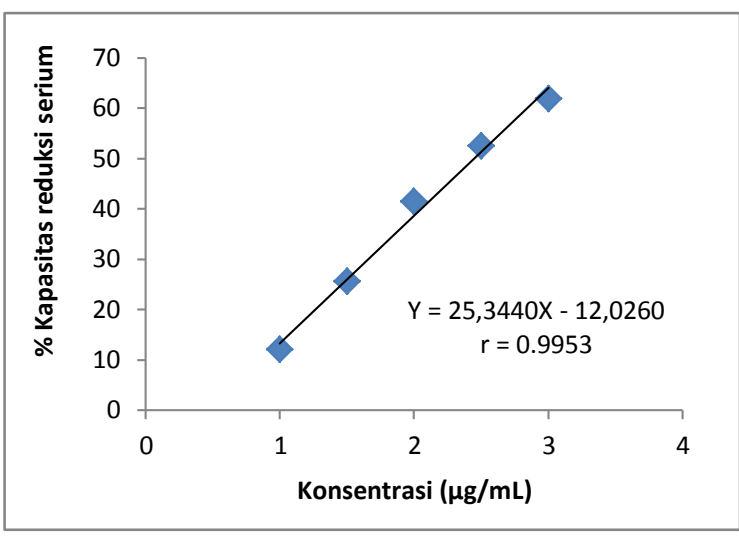

Gambar 3. Kurva hubungan antara konsentrasi sediaan rebusan dengan \% kapasitas reduksi serium

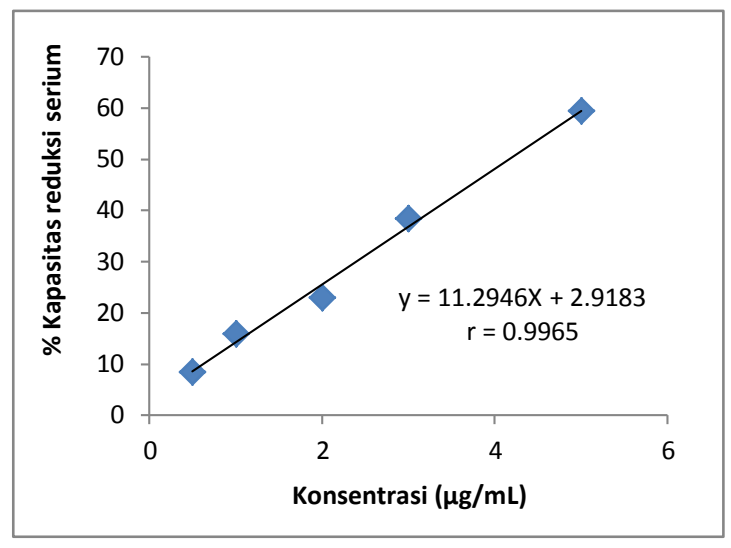

Gambar 5. Kurva hubungan antara konsentrasi vitamin $\mathrm{C}$ dengan \% kapasitas reduksi serium

tersebut dipengaruhi oleh sifat senyawa fenolik yang lebih mudah larut dalam air karena memiliki kecenderungan berada dalam kondisi berikatan dengan gula sebagai glikosida. Senyawa fenolik banyak terdapat di dalam dinding sel maupun cairan vakuola karena berfungsi untuk mencegah pembusukan jaringan pada tumbuhan. Pada proses penyeduhan dan perebusan, serbuk kering sarang semut mengalami kontak langsung dengan panas yang dihasilkan oleh air mendidih sehingga dinding sel dan membran plasmacepat mengalami kerusakan yang memudahkan air masuk ke dalam dinding sel dan vakuola untuk melarutkan senyawa fenolik. Hal inilah yang mempengaruhi sampel seduhan dan rebusan memiliki kandungan fenolik total yang lebih tinggi dibanding ekstrak.

Berdasarkan pengukuran aktivitas antioksidan, semua cara pemanfaatan sarang semut mampu memberikan aktivitas antioksidan yang sangat kuat dengan $\mathrm{EC}_{50}$ kurang dari 50 ppm, dengan urutan $\mathrm{EC}_{50}$ terkecil yaitu sediaan rebusan, ekstrak, seduhan. Pemanasan pada proses perebusan mampu membuka 
jaringan dan memecah sel, sehingga komponen aktif yang awalnya tidak muncul dapat tertarik keluar. Hal ini didukung dengan hasil penelitian sebelumnya (Dhurhania \& Purwanti, 2015) yang menunjukkan bahwa sampel rebusan sarang semut memiliki kandungan flavonoid yang paling tinggi dibanding sampel seduhan dan ekstrak, sehingga sampel rebusan memiliki aktivitas antioksidan dengan nilai $\mathrm{EC}_{50}$ terkecil.

Aktivitas antioksidan pada sediaan ekstrak juga dipengaruhi oleh adanya komponen aktif lain yang berpotensi sebagai sumber antioksidan pada sarang semut. Penelitian sebelumnya (Dhurhania \& Purwanti, 2015) membuktikan bahwa hanya sediaan ekstrak kering sarang semut yang mampu mengambil senyawa tokoferol yang terkandung dalam tumbuhan sarang semut hingga mencapai 1042 ppm. Kandungan tokoferol dalam ekstrak kering tersebut hampir 3,5 kali lebih tinggi dari tokoferol yang terdapat dalam tumbuhan sarang semut itu sendiri. Tokoferol tidak mampu tersari dalam sediaan seduhan maupun rebusan karena tokoferol tidak dapat larut dalam air namun mudah larut dalam etanol $70 \%$.

\section{KESIMPULAN}

Sediaan sarang semut yang dapat menyajikan kandungan fenolik total dari kadar yang paling tinggi, yaitu seduhan, rebusan, ekstrak. Namun seluruh cara pemanfaatan sarang semut, mampu memberikan aktivitas antioksidan yang sangat kuat dengan $\mathrm{EC}_{50}$ kurang dari $50 \mathrm{ppm}$, bahkan sampel rebusan dan ekstrak kering lebih kuat dari vitamin C. Dengan demikian untuk mendapatkan kandungan fenolik yang paling tinggi dengan aktivitas antioksidan yang sangat kuat, serbuk bahan kering sarang semut sebaiknya dikonsumsi dalam bentuk seduhan.

\section{UCAPAN TERIMAKASIH}

Ucapan terima kasih disampaikan kepada Direktorat Penelitian dan Pengabdian kepada Masyarakat, Direktorat Jenderal Pendidikan Tinggi Republik Indonesia, yang telah mendanai penelitian ini.

\section{DAFTAR PUSTAKA}

Apriyanti, E. A., Satari, M. H. \& Laksono, B. (2016). Perbedaan Potensi Antibakteri Ekstrak Metanol Umbi Sarang Semut (Myrmecodia pendens Merr. \& Perry) dan $\mathrm{NaOCl}$ terhadap Streptococcus mutans (ATCC 25175). Jurnal
Kedokteran Gigi Universitas Padjajaran; 28; 106-112.

Attamimi, F. A., Ruslami, R. \& Maskoen, A. M. (2017). Uji Aktivitas Antibakteri Ekstrak Kasar Umbi Sarang Semut (Myrmecodia pendens) dibanding dengan Klorheksidin terhadap Streptococcus sanguinis. Majalah Kedokteran Bandung; 9; 94-101.

Dewi, Y. S. K. \& Dominika. (2008). Aktivitas Antioksidasi Ekstrak Fenol Umbi Sarang Semut (Hydnophytum sp.) pada Berbagai Suhu Penyeduhan. Agritech; 28; 91-96.

Dhurhania, C. E. \& Purwanti. (2015). The Effect of The Way to Use Sarang Semut (Myrmecodia pendens) in Cancer Treatment against Antioxidant Activity, Tocopherol Content, and Total Flavonoids. Prosiding; Aptisi Komisariat II, Surakarta.

Fatmawati, D., Puspitasari, P. K. \& Yusuf, I. (2011). Efek Sitotoksik Ekstrak Etanol Sarang Semut (Myrmecodia pendens) pada Sel Line Kanker Serviks Hela. Sains Medika; 3; 112-120.

Kurniawati, E. \& Sianturi, C. Y. (2016). Manfaat Sarang Semut (Myrmecodia pendens) sebagai Terapi Antidiabetes. Majority; 5; 38-42.

Lung, J. K. S. \& Destiani, D. K. (2017). Uji Aktivitas Antioksidan Vitamin A, C, E dengan metode DPPH. Farmaka; 15; 53-62.

Noya, E., Buang, Y. \& Cunha, T. D. (2013). Isolasi, Identifikasi, dan Uji Aktivitas Senyawa Antioksidan Fraksi Kloroform Ekstrak Metanol Sarang Semut (Myrmecodia pendens). Jurnal Kimia Terapan; 1; 6-11.

Nugroho, A. E., Malik, A. \& Pramono, S. (2013). Total Phenolic and Flavonoid Contents of and in vitro Antihypertension Activity of Puriffied Extract of Indonesian Cashew Leaves (Anacardium occidentale L.). International Food Research Journal; 20; 299-305.

Sabri, S. (2011). Aktivitas Antioksidan dan Komponen Bioaktif Kangkung Air (Iponemoea aquatica Forsk). Skripsi; Fakultas Perikanan dan Ilmu Kelautan Institut Pertanian Bogor, Bogor.

Setianingsih, N. (2013). Potensi Antioksidan Ekstrak Sarang Semut (Myrmecodia pendens): Pengaruh Bentuk Sarang Semut, Suhu Ekstraksi, Konsentrasi terhadap Aktivitas Antioksidan. Thesis; Fakultas Ilmu dan Teknologi Pangan Universitas Jenderal Soedirman, Purwokerto. 
Soeksmanto, A., Subroto, M. A., Wijaya, H. \& Simanjuntak, P. (2010). Anticancer Activity Test for Extracts of Sarang Semut Plant (Myrmecodia pendens) to Hela and MCM-B2 cells. Pakistan Journal of Biological Science; 13; 148-151.

Suharyanto, Wahyudi, D. \& Lindawati, N. Y. (2013). Metode Ekstraksi Sarang Semut (Myrmecodia Pendens) dengan Teknik Maserasi untuk Menghasilkan Obat Alternatif Kanker Paru. Lembaga Penelitian dan Pengabdian kepada Masyarakat. Prosiding; Semnas Sains \& Entrepreneurship I, Semarang.

Raya, M. K., Legowo, A. M. \& Wijayahadi, N. (2016). Efektivitas Ekstrak Umbi Sarang Semut sebagai Penurun Kadar Glukosa Darah Tikus Sprague dawley yang Diabetes Mellitus. Jurnal Gizi Indonesia; 4; 138-144.
Rosyadi, I. \& Hariono, B. (2017). Potensi Imunologi Serbuk Umbi Tanaman Sarang Semut (Myrmecodia tuberose) terhadap Tikus Wistar yang Diinduksi Streptozotocin. Jurnal Sain Veteriner; 35; 159-164.

Yessica, P. (2012). Uji Sitotoksisitas Ekstrak Etanol Sarang Semut (Myrmecodia pendens Merr \& Perry) terhadap Carsinoma Mammae pada Kultur Sel MCF-7. Skripsi; Fakultas Kedokteran Universitas Kristen Maranatha, Bandung. 